\title{
Prevalence of Hypertension among the Bangladeshi Adult Population: A meta-analysis of Studies between 2004 and 2014
}

\author{
Shaibal Chowdhury ${ }^{1}$, Purnima Chowdhury ${ }^{2}$ \\ ${ }^{1}$ Department of Public Health, North South University, Dhaka, ${ }^{2}$ Department of Hospital Management, \\ National Institute of Preventive and Social Medicine (NIPSOM), Dhaka
}

Key Words : Hypertension, Smoking, Physical activities.

\begin{abstract}
:
Background: Hypertension has become a significant problem in many developing countries undergoing epidemiological transition from communicable to non-communicable chronic diseases. Previous studies covering up to 1999 reported a prevalence of $l l .3 \%$ in the adult population of Bangladesh.

Methods: We have searched National Institute of Cardiovascular Diseases (NICVD) Library and PubMed@Resources Guide for published Hypertension prevalence studies between 2004 and 2014. A meta-analysis was conducted to estimate the prevalence of hypertension among the adult Bangladeshi population. We have considered population-based studies that had a clear definition of hypertension, and were conducted in adults (>18 years). We have marked seventeen articles, of which only six articles fulfill the selection criteria were included for the current analysis. Then the prevalence of hypertension and their $95 \%$ CIs for the individual studies were calculated by using the data presented. Finally a pooled estimate was obtained from six studies.

Results: The pooled estimate for the prevalence of hypertension in 2972 adults was 20.88\% (18.75\% - 22.87\%) which almost double than the previous estimated value.

Conclusion: The meta-analysis clearly demonstrates the high burden of hypertension among the adult population of rural Bangladesh and underscores the importance of instituting screening for asymptomatic individuals with potentially harmful hypertensive disorder, especially in primary health-care settings to combat the growing epidemic of Noncommunicable Diseases. Large scale studies can be done including all the high risk population to represent the actual scenario of hypertension in Bangladeshi adult population.
\end{abstract}

(Cardiovasc. j. 2015; 7(2): 104-107)

\section{Introduction:}

An epidemiological shift in the prevalence of hypertension in developing countries as compared to developed countries has been observed. Studies from India and Bangladesh are shown upward trend in the prevalence of hypertension. The prevalence of hypertension has increased by 30 times among the urban population over period of 55 years and about 10 times among the rural population over a period of 36 years.

Various hypotheses have been put forward to explain this rising trend and among these, consequence of urbanization such as change in life style pattern, diet and stress have been implicated.
Dramatic changes in life style from traditional to modern have lead to physical inactivity due to technological advances. Rising affluences has modified the dietary pattern characterized by increased consumption of diet rich in fat, sugar and calories.

Furthermore, increasing population growth and technological advances have shrunken the employment opportunities particularly among the young generation-leading to stress and hypertension in young person's including students and laborers.

Developing counties are increasingly faced with the double burden of hypertension and other

Address of Correspondence: Dr. Shaibal Chowdhury, Department of Public Health, North South University, Dhaka, Bangladesh.email: shaibalbd@gmail.com 
cardiovascular diseases along with infection and malnutrition. Hypertension places an excessive financial burden on population and health systems, consuming scarce resources. Population based preventive approaches are thus central for the management of hypertension in developing countries, where clinic-based care for complication is not feasible option.

There is a lack of representative data on the prevalence of hypertension in the Bangladeshi population. One meta-analysis conducted in 1999 on the prevalence of hypertension in the Bangladeshi adult population included studies from 1976 to 1994 and estimated the prevalence to be $11.3 \%$. Between 1995 and 2009, some more studies with small sample sizes were conducted, which showed varying prevalence rates. Individually, these studies cannot provide sufficient information about the prevalence in the country due to the non-representativeness of the study populations as well as the small sample sizes. In order to efficiently utilize the information available from these surveys, we decided to conduct another meta-analysis of previous population-based studies from 2004 to 2014 in Bangladesh for a more accurate estimation of the prevalence of hypertension.

\section{Methods:}

For this meta-analysis, articles published from 2004 to 2014 on the prevalence of hypertension among the Bangladeshi adult population by conducting a search in NICVD Library and PubMed@Resources were identified. The population-based studies that had a clear diagnostic definition of hypertension and were conducted in the age group $>18$ years, were included in the meta analysis. Only 6 articles for the current analysis were identified because they fulfill the selection criteria. These were studies done in clinical settings like diabetic subjects, pregnant women, with arsenicosis among the elderly population ( >60 years). The prevalence of hypertension in these studies and the $95 \%$ confidence intervals (CI) for the individual studies using the data presented was calculated. Finally, the denominators (total number of subjects studied) and numerators (total number of subjects identified with hypertension) from each study to get the pooled prevalence estimate with its $95 \%$ CI were added.

\section{Results:}

Table I summarizes the studies on the prevalence of hypertension in the Bangladeshi adult population from 2004 to 2014, and the calculated prevalence rates and their $95 \%$ of confidence intervals. All studies were done in rural Bangladesh and thus the results can be used as an estimate only for rural Bangladesh. All studies included adults $>18$ years of age. The prevalence of hypertension in these studies ranged from $13.3 \%$ to $30.64 \%$.

All studies used the definition of hypertension proposed by WHO in 1993, which defines hypertension as systolic and/or diastolic blood pressure (>140/90mmHg) with or without a history of taking antihypertensive medication.

Table I provides the pooled estimate of the prevalence of hypertension as measured from the studies that met the eligibility criteria for this meta-analysis. From a total of 2972 adults included in these studies, we arrived at an estimate of $20.88 \%$ ( with $95 \%$ CIs ranging from $18.75 \%$ to $22.87 \%)$.

\section{Observation:}

On analysis, the prevalence of hypertension (20.88\%) observed in this study was higher than the previous study. This meta-analysis included studies conducted mainly among the rural community, which report a much lower prevalence and therefore, probably have reflected the increase in the prevalence of hypertension in urban areas. Even prevalence of hypertension showed a moderate increase in rural population which is higher than the previous study. Being female, older, obese, diabetic, having a higher education, or from a higher socioeconomic status were significantly associated with a higher prevalence of hypertension. High prevalence of hypertension was observed in patients with positive family history, smoking and less physical activity. 
Table-I

Studies on hypertension in Bangladesh from 2004 to 2014 identified in NICVD library and Pubmed search

\begin{tabular}{|c|c|c|c|c|c|c|c|c|c|c|c|c|c|}
\hline \multirow{2}{*}{$\begin{array}{l}\text { Year of } \\
\text { publication }\end{array}$} & \multirow{2}{*}{$\begin{array}{l}\text { Place and } \\
\text { year of study }\end{array}$} & \multirow[t]{2}{*}{ Subjects } & \multirow{2}{*}{$\begin{array}{l}\text { Sampling } \\
\text { procedure }\end{array}$} & \multirow{2}{*}{$\begin{array}{l}\text { Respon } \\
\text { se rate } \\
(\%)\end{array}$} & \multirow{2}{*}{$\begin{array}{l}\text { Number } \\
\text { of } \\
\text { readings } \\
\text { taken }\end{array}$} & \multirow{2}{*}{$\begin{array}{l}\text { Criteria } \\
\text { for } \\
\text { diagnos } \\
\text { is of } \\
\text { HTN }\end{array}$} & \multirow{2}{*}{$\begin{array}{l}\text { Age } \\
\text { group } \\
\text { (years) }\end{array}$} & \multirow{2}{*}{$\begin{array}{l}\text { Sample } \\
\text { size }\end{array}$} & \multirow{2}{*}{$\begin{array}{l}\text { Prevalenc } \\
\text { e }\end{array}$} & \multicolumn{4}{|c|}{ Meta analysis } \\
\hline & & & & & & & & & & Age & No & $\mathrm{P}(\%)$ & $\begin{array}{l}95 \% \\
\mathrm{CI}\end{array}$ \\
\hline $\begin{array}{l}\text { Zaman } \\
\text { MM } \\
2004\end{array}$ & $\begin{array}{l}\text { Rural } \\
\text { community, } \\
\text { matlab, } \\
\text { Chandpur } \\
\text { district 1999- } \\
2002 \\
\end{array}$ & $\begin{array}{l}\text { Clinic based } \\
\text { rural } \\
\text { population }\end{array}$ & All & 100 & One & $\begin{array}{l}\text { WHO } \\
\text { criteria }\end{array}$ & $>20$ & 1271 & 17.8 & \multicolumn{4}{|c|}{ Not included } \\
\hline $\begin{array}{l}\text { Sayeed } \\
\text { MA } \\
2005\end{array}$ & $\begin{array}{l}\text { Randomly } \\
\text { selected } 10 \\
\text { villages of } \\
\text { nandail } \\
\text { subdistrict, } \\
\text { Mymenshingh } \\
2001-2002 \\
\end{array}$ & $\begin{array}{l}\text { Pregnant } \\
\text { women }\end{array}$ & $\begin{array}{l}\text { Not } \\
\text { reported }\end{array}$ & $\begin{array}{l}\text { Not } \\
\text { reporte } \\
\text { d }\end{array}$ & $\begin{array}{l}\text { Not } \\
\text { reported }\end{array}$ & $\begin{array}{l}\text { WHO } \\
\text { criteria }\end{array}$ & $18-44$ & 147 & $\begin{array}{l}\text { SBP } 6.8 \\
\text { and DBP } \\
5.4\end{array}$ & \multicolumn{4}{|c|}{ Not included } \\
\hline $\begin{array}{l}\text { Chen Y } \\
2006\end{array}$ & $\begin{array}{l}\text { Araihazar } \\
2000-2002\end{array}$ & $\begin{array}{l}\text { Rural } \\
\text { Bangladeshis } \\
\text { with } \\
\text { exposure to } \\
\text { Arsenic }\end{array}$ & $\begin{array}{l}\text { Not } \\
\text { reported }\end{array}$ & 97.5 & $\begin{array}{l}\text { Three } \\
\text { recordings } \\
\text {, lowest } \\
\text { one was } \\
\text { taken }\end{array}$ & $\begin{array}{l}\text { WHO } \\
\text { criteria }\end{array}$ & 18 & 11116 & 13.3 & \multicolumn{4}{|c|}{ Not included } \\
\hline $\begin{array}{l}\text { Zaman } \\
\text { MM } \\
2007\end{array}$ & $\begin{array}{l}\text { Ekhlusur } \\
\text { village, } \\
\text { Chandpur } \\
\text { district 2001 } \\
\end{array}$ & $\begin{array}{l}\text { Rural } \\
\text { Bangladeshis }\end{array}$ & $\begin{array}{l}\text { Simple } \\
\text { random } \\
\text { sampling }\end{array}$ & 64 & One & $\begin{array}{l}\text { WHO } \\
\text { criteria }\end{array}$ & $\begin{array}{l}20, \\
\text { mean } \\
40\end{array}$ & $\begin{array}{l}700, \\
\text { actual } \\
447\end{array}$ & 18.6 & 20 & 440 & 18.6 & $\begin{array}{l}15.0- \\
22.2\end{array}$ \\
\hline $\begin{array}{l}\text { Van Minh } \\
\text { H } 2009\end{array}$ & $\begin{array}{l}\text { Matlab, } \\
\text { Mirsarai, } \\
\text { Abhoynagar } \\
\text { and WATCH } \\
\text { area } 2005\end{array}$ & $\begin{array}{l}\text { Rural } \\
\text { Bangladeshis }\end{array}$ & $\begin{array}{l}\text { Multistage } \\
\text { cluster } \\
\text { sampling }\end{array}$ & 98 & $\begin{array}{l}\text { Mean of } \\
\text { three } \\
\text { recordings }\end{array}$ & $\begin{array}{l}\text { WHO } \\
\text { criteria }\end{array}$ & $25-64$ & 2000 & 13.4 & $25-64$ & 2000 & 13.4 & $\begin{array}{l}11.9- \\
14.9\end{array}$ \\
\hline $\begin{array}{l}\text { Rahim } \\
\text { MA } 2012\end{array}$ & $\begin{array}{l}\text { Jhaldhaka, } \\
\text { Nilphamari } \\
2008\end{array}$ & $\begin{array}{l}\text { Rural } \\
\text { Bangladeshis }\end{array}$ & $\begin{array}{l}\text { Simple } \\
\text { random } \\
\text { sampling }\end{array}$ & $\begin{array}{l}\text { satisfac } \\
\text { tory }\end{array}$ & One & $\begin{array}{l}\text { WHO } \\
\text { criteria }\end{array}$ & $20-70$ & 532 & 30.64 & $20-70$ & 532 & 30.64 & $\begin{array}{l}29.36- \\
31.53\end{array}$ \\
\hline & & & & & & & & Poole & timate of & ertension & 2972 & 20.88 & $\begin{array}{l}18.75- \\
22.87\end{array}$ \\
\hline
\end{tabular}

\section{Discussion:}

Through this meta-analysis, we attempted to provide information on the prevalence of hypertension in the Bangladeshi adult population. For this purpose, we searched articles published in PubMed Resources Guide during the years 19952009 on the prevalence of hypertension in Bangladeshi adults.

It was found that a prevalence of hypertension of $20.88 \%$ in the adult population of Bangladesh, which was higher than the $11.3 \%$ prevalence reported by Zaman and Rouf in 1999. However the previous meta-analysis included studies conducted in Dhaka only and mostly urban areas, where the prevalence of hypertension has been found to be higher, while our meta-analysis included studies conducted mainly among the rural community, which report a lower prevalence and would, therefore, probably have underestimated the increase in the prevalence of hypertension. With increasing urbanization, this segment of the population is of great relevance to non communicable disease (NCD) prevention and control. On a similar note, using a single or a group of villages in a certain geographic location may not capture the disease prevalence for a country with approximately 68 thousand villages.

A general difficulty was to gather all the published data on hypertension for the review period, since not all Bangladeshi journals are available electronically, and those that have electronic text came into existence recently. Although a number of full text articles that were otherwise unavailable in the Web through personal communications with Bangladeshi researchers were collected, and have to rely on the abstract for a few studies.

\section{Recommendations:}

Although an adequate number of hypertension prevalence studies have been conducted, they were mostly done in and outside the city areas, leaving many regions of the country unstudied. Few data exist on the prevalence of other cardiovascular diseases such as ischemic heart disease. We recommend that future prevalence studies focus 
on the gaps identified in this review. In addition, we suggest that samples of the future studies are selected systematically, according to the administrative structure of the country (division, district, upazila, etc.), in order to capture any differences in disease prevalence by geographical regions. We did not find any longitudinal cohort studies on HTN. This is a significant gap in the knowledge and understanding of these chronic diseases in the context of Bangladesh. Such studies would provide essential information on the incidence of these diseases, their associated risk factors, and the groups that are at higher risk of developing with understanding the disease progression and prognosis. Development of a cohort study would require considerable effort and data would not be available for many years. In the mean time, retrospective cohort studies could be conducted using medical records available in various government (NICVD-National Institute of Cardiovascular Diseases) and private institutions (ICDDR,B-International Center on Diarrheal Diseases and Research, Bangladesh; BIRDEMBangladesh Institute of Research and Rehabilitation for Diabetes, Endocrine, and Metabolic Disorders; NHF National Heart Foundation). Such retrospective studies could begin to address some of the research issues outlined above such as disease complications and treatment adherence.

\section{Conclusion:}

The prevalence of hypertension in the rural population was found to be on the increased compared to previous reports of Bangladesh. The study thus underscores the importance of screening asymptomatic individuals. Every adult's blood pressure should be checked. Primary healthcare centers, community clinics and all health-care facilities should implement this strategy for the prevention and control of hypertension. Although this simple meta-analysis does not provide data representative of Bangladesh, it gives a more informative estimate than individual studies do.
More studies are suggestive to evaluate the prevalence of hypertension in the rural population of Bangladesh.

Conflict of Interest - None.

\section{References:}

1. Nissien A, Bothig S, Grenroth H, Lopez AD. Hypertension in developing countries. World Health Stat Q 1988; 41: 141-154.

2. Reddy KS. Hypertension control in developing countries: generic issues. J Hum Hypertens 1996; 10: 33-38.

3. Gupta R. Meta analysis of prevalence of hypertension in India. Indian Heart Journal 1997; 49: 43-48.

4. Hussain SA, Nayak KC, Gupta A. A study of prevalence of hypertension with reference to economic, educational, environmental and hereditary factors in general population of North-West Rajasthan. Indian Heart Joumal 1988; 40: 148-151.

5. Zaman MM, Choudhury SR, Ahmed J, Numan SM, Islam MS, Yoshiike N. Non-biochemical risk factors for cardiovascular disease in general clinic-based rural population of Bangladesh. J Epidemiol 2004; 14(2):6368.

6. Sayeed MA, Mahtab H, Khanam PA, Begum R, Banu A, Azad Khan AK. Diabetes and hyertension in pregnancy in a rural community of Bangladesh: a population based study. Diabet Med 2005; 22(9): 1267-1271.

7. Chen Y, Factor-Litvak P, Howe GR, Parvez F, Ahsan H. Nutritional influence on risk of high blood pressure in Bangladesh: a population-based cross-sectional study. Am J Clin Nutr 2006; 84(5):1224-1232.

8. Zaman MM, Almed J, Choudhury SR, Numan SM, Parvin K, Islam MS. Prevalence of ischemic heart disease in a rural population of Bangladesh. Indian Healt $J$ 2007; 59(3):239- 241.

9. Van Minh H, Soonthornthada K, Ng N, Juvekar S, Razzaque A , Ashaf A, et al. Blood pressure in adult rural INDEPTH population in Asia. Glob Health Action $2009 ; 2$.

10. Rahim MA, Rahman MM, Rahman M, Ahmed F, Chowdhury J, Islam F. The Prevalence rate of Hypertension in Rural Population of Bangladesh. $J$ Dhaka National Med Coll Hos 2012; 18(1):12-17.

11. Zaman MM, Rouf MA, Prevalence of hypertension in a Bangladeshi adult population. J Hum Hypertens 1999; 13(8): 547-549. 